\title{
Economic Burden of Multiple Sclerosis on patients: Research Findings from Greece
}

\author{
Athanassios Vozikis ${ }^{1, *}$, Eleni Sotiropoulou ${ }^{2}$ \\ ${ }^{1}$ Economics Department, University of Piraeus, Piraeus, Greece \\ ${ }^{2}$ Informatics Department, University of Piraeus, Piraeus, Greece \\ *Corresponding author: avozik@unipi.gr
}

Received December 31, 2013; Revised June 20, 2013; Accepted June 21, 2013

\begin{abstract}
The Multiple Sclerosis (MS) is a chronic autoimmune, inflammatory disease, which is the third cause of serious disability for the ages between 20 and 40 years old. More than 8,000 Greeks suffer from this disease. The scope of our research is to estimate the economic burden on patients with MS, through the analysis of their out - of pocket payments. The study was conducted in 2010 to a random sample of 400 patients, from whom 288 (103 men and 185 women) completed the research questionnaire. The average annual out - of - pocket payments of MS patients, found to be $8,334 €$, significantly varying by the gender and the severity of the disease. From our research it was unveiled the significant economic burden on patients with MS in Greece. Consequently, it is appointed the imperative need of research on the social and economic cost of MS and of introducing an integrated support system for the patients.
\end{abstract}

Keywords: multiple sclerosis, health economics, out - of- pocket payments, cost of illness, Greece

\section{Introduction}

TheMS is a chronic autoimmune, inflammatory disease, which has variety of symptoms [1]. The causes of MS are not yet found although scientists know the disease's pathophysiology.Common symptoms, include upper and lower extremity disabilities, visual disturbances, balance and coordination problems etc $[2,3,4,5]$.

Patients and their families experience major changes in their lives on a social and professional level as well as in their day to day life [6,7]. TheMS is the third cause of serious disability for the ages between 20 and 40 years old with current prevalence rates estimated to 30 per 100,000 populations. Generally, MS affects more 1 million young people all over the world and globally 200 individuals are diagnosed weekly with the disease [9-16]. It is estimated that there are about 250,000 Americans, 80,000 British and 8,000 Greeks suffering from the disease.

Interesting research has been done in various countries in order to estimate the financial burden of the disease, as well as to bring forward the consequences of the disease for the patients and their families [17-26].

Table 1, presents the cost analysis of MS in various countries, as it was estimated in 2007 bycombined studies [27].

In Greece, unlike other European countries, no sufficient research to estimate the cost of the illness has been carried out, except from the one of the Greek Society for MS which conducted to a limited sample of 43 patients with MS [28].

\section{Materials and Methods}

The scope of this paper is to estimate and present the economic burden on patients with MS, through the analysis of their out - of - pocket payments and the reduction of their annual income.

A total of 400 patients were included in the study, from which 288 completed the research questionnaire. The response rate was 0.72 . The patients were 103 men and 185 women aged $>=15$ years, who had clinically or laboratory supported definite MSaccording to neurologist, the diagnosis of the MS have been onset at least 12 months before starting the study, regardless of time of symptoms. Patients were excluded if they had other acute or chronic illness.

The study was conducted during the period March to July 2010, from various regions of Greece. We used a reliable and weighted questionnaire which consisting of 91 questions given by the Greek Society for MS (but adapted to the needs of our research). Furthermore to identify patterns of the disease (level of functional disability), the questionnaire asked for information on resource consumption, medical and non-medical expenditure, work absenteeism and informal care. The patients were called to participate in the study voluntarily, they were informed for its purpose via letter which was attached to the questionnaire and they first signed the relevant consent statement. Also, the questionnaire was completed through personal interviews with the patients or their family members. Finally, the questionnaire used to MS specific tools; the Expanded Disability Status Scale [29], the Multiple Sclerosis Quality of Life (MSQOL - 54) 
[30], the Multiple Sclerosis Impact Scale (MSIS -29) [31], which have been also used in several studies. Finally, the statistical analysis of the study was conducted using the SPSS 17.00 and Excel 2007.

Table 1. Financial cost of MS (in US Dollars)

\begin{tabular}{|c|c|c|c|c|}
\hline Country & $\begin{array}{c}\text { Total Direct } \\
\text { Medical } \\
\text { Costs } \\
(2007)\end{array}$ & $\begin{array}{c}\text { Total Direct } \\
\text { Non } \\
\text { Medical } \\
\text { Costs } \\
(2007) \\
\end{array}$ & $\begin{array}{c}\text { Total } \\
\text { Indirect } \\
\text { Costs } \\
(2007)\end{array}$ & $\begin{array}{c}\text { Total Cost } \\
\text { (2007) }\end{array}$ \\
\hline Australia & $\$ 18,809$ & $\$ 16,167$ & $\$ 6,890$ & $\$ 41,866$ \\
\hline Austria & $\$ 20,738$ & $\$ 10,010$ & $\$ 17,569$ & $\$ 48,317$ \\
\hline Belgium & $\$ 13,746$ & $\$ 10,108$ & $\$ 13,267$ & $\$ 37,121$ \\
\hline Canada & $\$ 3,162$ & $\$ 2,421$ & $\$ 15,932$ & $\$ 21,514$ \\
\hline France & $\$ 6,078$ & $\$ 4,718$ & $\$ 5,582$ & $\$ 16,378$ \\
\hline Germany & $\$ 20,246$ & $\$ 6,986$ & $\$ 19,946$ & $\$ 47,178$ \\
\hline Italy & $\$ 13,001$ & $\$ 19,225$ & $\$ 13,237$ & $\$ 45,462$ \\
\hline Netherlands & $\$ 9,845$ & $\$ 8,910$ & $\$ 15,849$ & $\$ 34,605$ \\
\hline Norway & $\$ 10,995$ & $\$ 12,472$ & $\$ 31,023$ & $\$ 54,489$ \\
\hline Poland & $\$ 3,495$ & $\$ 2,713$ & $\$ 11,423$ & $\$ 17,631$ \\
\hline Spain & $\$ 15,973$ & $\$ 16,498$ & $\$ 11,544$ & $\$ 44,015$ \\
\hline Sweden & $\$ 15,431$ & $\$ 21,607$ & $\$ 17,427$ & $\$ 54,465$ \\
\hline Switzerland & $\$ 10,211$ & $\$ 13,365$ & $\$ 14,473$ & $\$ 38,048$ \\
\hline $\begin{array}{c}\text { United } \\
\text { Kingdom }\end{array}$ & $\$ 10,969$ & $\$ 19,858$ & $\$ 17,995$ & $\$ 48,822$ \\
\hline $\begin{array}{l}\text { United } \\
\text { States }\end{array}$ & $\$ 23,975$ & $\$ 7,844$ & $\$ 18,888$ & $\$ 50,707$ \\
\hline
\end{tabular}

Source: Tsitsolini M, Honeycutt A, Wiener J, Lesesne S, «Global economic impact of Multiple Sclerosis», MSIF, London, United Kingdom, 2010

\section{Results}

\subsection{Sample Demographics}

Table 2 presents the sample (patients) characteristics. A total of 288 patients were included in the analysis. The mean age was 46.2 years, $35.8 \%$ were male and $64.2 \%$ female. Moreover, the majority of patients was married (55.6\%) and had children, while $81.9 \%$ live in the big city. On the other hand, $8.7 \%$ live in the village. $34.7 \%$ indicated unemployed and their family help them to cover the costs of MS. Furthermore, 54.2\% of the patients are insured in Social Insurance Institute. Finally, 52.8\% of the survey, the primary care for patients comes from their family, which confirms that in Greece the family has undertaken to support both financially and psychologically people with Multiple Sclerosis, hence affecting and changing the everyday life of their close relay.

Table 2. Demographics of the Sample

\begin{tabular}{|c|c|c|}
\hline Gender & Frequencies & Percent \\
\hline Male & 103 & 35.8 \\
\hline Female & 185 & 64.2 \\
\hline Total & 288 & 100 \\
\hline Age & & \\
\hline Mean age: $\mathbf{4 6 . 2}$ & & \\
\hline $15-24$ & 6 & 2.1 \\
\hline $25-39$ & 38 & 13.2 \\
\hline $40-54$ & 169 & 58.7 \\
\hline $55-64$ & 51 & 17.7 \\
\hline $65-79$ & 7 & 2.4 \\
\hline Missing & 17 & 5.9 \\
\hline Total & $\mathbf{2 8 8}$ & $\mathbf{1 0 0}$ \\
\hline
\end{tabular}

\subsection{Financial Burden on the Patients (Out - of - Pocket Payments)}

Before mentioning the findings of our research we should clarify that almost all studies are based on the EDSS scale for determining the financial cost of MS. In our study 69.5 percent of patients had mild disease (Expanded Disability Status Scale [EDSS] score of 0-3), 27.6\% had moderate disease (EDSS score of 4-6.5) and $3 \%$ had severe disease (EDSS score of $\geq 7$ ). The mean EDSS score in the sample was 3. In Table 3, an allocation of the patients to the EDSS Score, is presented.

\begin{tabular}{|} 
Table 3. EDSS Score allocation \\
\begin{tabular}{|c|c|c|}
\hline EDSS Score & Frequencies & Percent \\
\hline 0 & 9 & 3.1 \\
\hline 1 & 51 & 17.7 \\
\hline 2 & 49 & 17 \\
\hline 3 & 91 & 31.6 \\
\hline 4 & 23 & 8 \\
\hline 5 & 54 & 18.8 \\
\hline 6 & 2 & 0.7 \\
\hline 7 & 3 & 1 \\
\hline 8 & 5 & 1.7 \\
\hline 9 & 1 & 0.3 \\
\hline Total & $\mathbf{2 8 8}$ & $\mathbf{1 0 0}$ \\
\hline
\end{tabular}
\end{tabular}

To test for whether there is any relationship between the variable Severity (EDSS Score) and the variables Gender and Age, we performed the chi-squared test. The results in Table 4 and Table 5show that there's a strong relationship.

Table 4. Age BY severity Chi-Square Test

\begin{tabular}{|c|c|c|c|}
\hline & Value & df & Asymp. Sig. (2-sided) \\
\hline Pearson Chi-Square & $37.316^{\mathrm{a}}$ & 9 & .000 \\
\hline Likelihood Ratio & 43.994 & 9 & .000 \\
\hline N of Valid Cases & 288 & & \\
\hline
\end{tabular}

a. 9 cells (45.0\%) have expected count less than 5. The minimum expected count is 36 .

Table 5. Gender BY severity Chi-Square Test

\begin{tabular}{|c|c|c|c|}
\hline & Value & df & Asymp. Sig. (2-sided) \\
\hline Pearson Chi-Square & $37.316^{\text {a }}$ & 9 & .000 \\
\hline Likelihood Ratio & 43.994 & 9 & .000 \\
\hline N of Valid Cases & 288 & & \\
\hline
\end{tabular}

a. 9 cells $(45.0 \%)$ have expected count less than 5 . The minimum expected count is .36 .

From our research it is found that the average annual income of the patients decreased by approximately $€$ 2,000, mainly during the first 2 years of the disease onset, a fact that leads to greater financial loss of patients due to the disease. This income decrease is mainly due the early loss of ability to work and the impact of physical and psychological disabilities.

Moreover, the average annual out - of - pocket payments of MS patients, found to be $€ 8,334$ varying by the gender ( $€ 8,942$ for women and $€ 7,241$ for men) (see Figure 1) and the severity of the disease (from $€ 3,629$ for EDSS $=0$ to $€ 22,800$ for EDSS $=9$ ) (see Figure 2). 


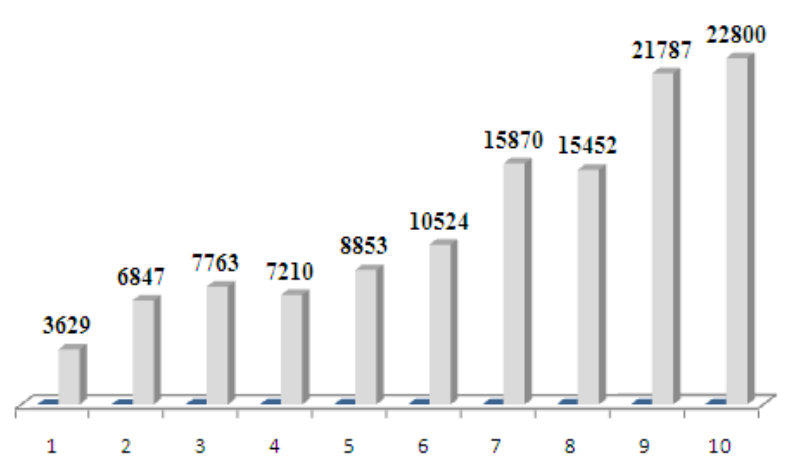

Figure 1. EDSS and average annual out - of - pocket payments

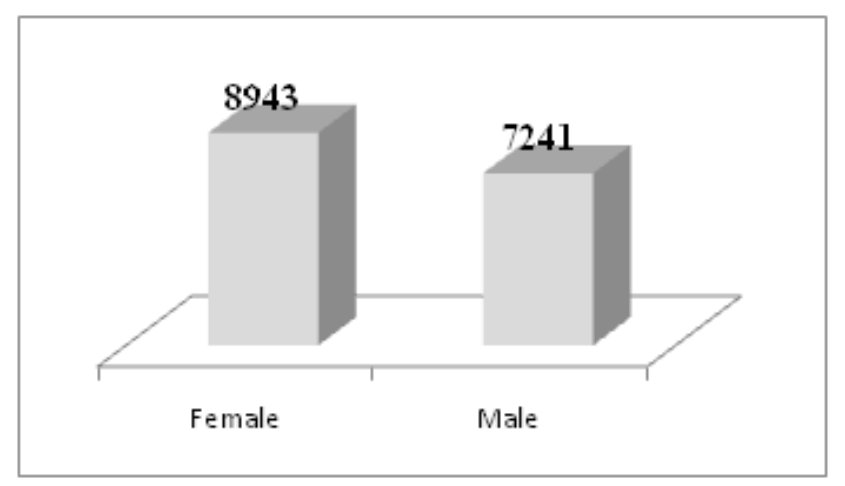

Figure 2. Gender and average annual out - of - pocket payments

We used a one-way ANOVA to explore the effect of the categorical variable (explanatory variable) Severity (EDSS Score)on the continuous variable (outcome) Total The results are shown in Table 6 and Figure 3.

Table 6. ANOVA for Total

\begin{tabular}{|c|c|c|c|c|c|}
\hline & $\begin{array}{c}\text { Sum of } \\
\text { Squares }\end{array}$ & df & Mean Square & F & Sig. \\
\hline $\begin{array}{c}\text { Between } \\
\text { Groups }\end{array}$ & 16890437.608 & 9 & 1876715.290 & 10.636 & .000 \\
\hline $\begin{array}{c}\text { Within } \\
\text { Groups }\end{array}$ & 48700677.361 & 276 & 176451.730 & & \\
\hline Total & 65591114.969 & 285 & & & \\
\hline
\end{tabular}

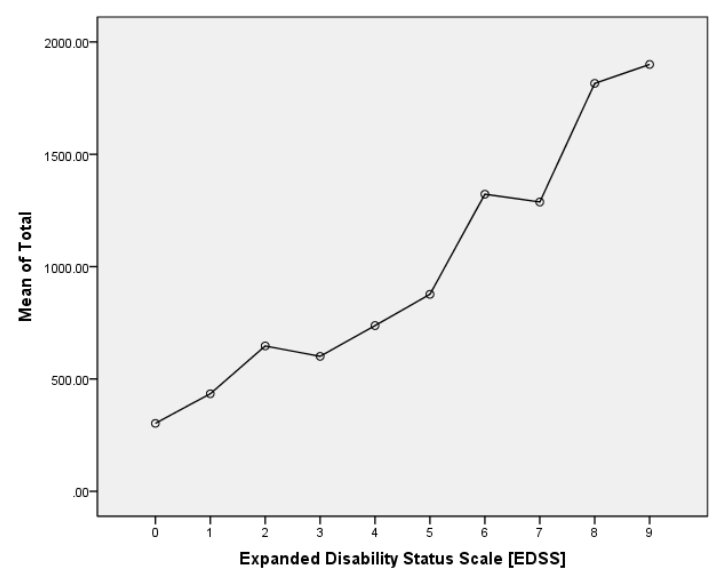

Figure 3. ANOVA for Total

For better fit the data, we excluded two (2) extreme values from the variable Total. In this model, the $F$ value, which is the between-group mean square dividedby the within-group mean square, is large at 10.636 and is significant at $P=0.000$. This indicates that there is a significant difference in the mean valuesof the 10 parity groups.
Finally, the average annual out - of- pocket payments for outpatient and others diagnostic medicals tests found to be $€ 1,853$, for doctors' visits $€ 1,894$, for inpatient $€$ 7,672 , for pharmaceuticals $€ 869$, for physiotherapy and rehab and gym $€ 1,780$, for alter treat and diet $€ 1,552$, for transportation $€ 1,304$ and for home adjustment $€ 2,130$ (See Table 7).

Table 7. Out - of - pocket payments for patients with Multiple Sclerosis

\begin{tabular}{|c|c|c|c|c|}
\hline $\begin{array}{c}\text { Out - of -pocket } \\
\text { payments }\end{array}$ & Frequencies & Minimum & Maximum & Mean \\
\hline $\begin{array}{c}\text { Diagnostic } \\
\text { medicals tests e.t.c }\end{array}$ & 236 & 120 & 25,800 & 1,853 \\
\hline Doctor visits / year & 163 & 240 & 18,000 & 1,894 \\
\hline Inpatient / year & 34 & 600 & 22,800 & 7,672 \\
\hline $\begin{array}{c}\text { Pharmaceuticals / } \\
\text { year }\end{array}$ & 220 & 180 & 8,400 & 869 \\
\hline $\begin{array}{c}\text { Physiotherapy and } \\
\text { gymnastics/ year }\end{array}$ & 161 & .00 & 12,996 & 1,780 \\
\hline Alter Treatanddiet & 97 & .00 & 6,000 & 1,552 \\
\hline $\begin{array}{c}\text { Transportations } \\
\text { and car / year }\end{array}$ & 165 & .00 & 14,400 & 1,304 \\
\hline Home Adjustment & 8 & 600 & 3,600 & 2,130 \\
\hline Total & 288 & 600 & 52,200 & 8,334 \\
\hline
\end{tabular}

\section{Discussion}

In comparison to other countries, Greece lacks sufficient research concerning MS financial impact [32]. This void leads to the absence of adequate support to the patients and their families. The benefits granted by the government are limited and therefore they cannot cover the significant out-of-pocket amounts for this specific disease, as it is a chronic disease. Patients depend mostly on their family for their daily needs and also for their financial support. This fact was confirmed by our research.

Although the health system in Greece should be open and accessible to everyone, its services are mainly concentrated in large cities. Therefore, patients with MS who live in rural regions must always move or travel to urban areas where they can have access to the proper health services. Unfortunately, this case causes increased out-of-pocket expenses, as these are not always and fully covered by the social security organization, though it is noteworthy that it covers a large amount of the total expenses for the patients with MS. Our research findings confirmed the previous Greek Society for MS study results [28]. Its study showed that $75 \%$ - $100 \%$ of the expenses are covered by social security schemes but the amounts provided are not enough to pay for special treatments.

For the calculation of all our research findings concerning the financial burden of MS, the EDSS scale must be used for adjustment. Specifically, the research which was carried out in the United Kingdom had an average EDSS rate of 5.1 [21], in Germany 4.4 [22], whereas in Greece, the rate is 3, which concludes that in our research the patients are fully peripatetic and have mediocre function disability. Nevertheless, patients with MS and their families have to adapt a new way of life, as their daily routine changes. Their direct and indirect expenses due to the disease are quite increased, therefore they are not always able to cover. This global problem, although its impact varies between various countries, is unveiled by our research in Greece too.

According to our findings, we can notice a significant reduction in the income of our sample with MS, especially 
during the first two years of the illness onset. Specifically, their average income before the disease was $€ 14,714$ one year later it is reduced to $€ 13,555$, five years later it was $€$ 12,824, a fact which points out a reduction of approximately $€ 2,000$.

In addition, our findings conclude that the average outof-pocket payments of the patients and their families in Greece amount to $€ 8,334$. Furthermore, we must mention that this amount is much more as the EDSS scale rises reaching the $€ 22,800$ when a patient is confined to bed (EDSS $=9-10)$, but it is rather lower $(€ 3,629)$ when EDSS $=0-1$.

If to the out-of-pocket expenses calculated above, we add the reduction of patients' income, because of its illness, the average financial burden per year escalates to $€$ 10,334. This amount might be considered much higher in the case that the patients with MS are unable to work any longer (something quite common) or if a family member stops working to stay home and take care of them [33].

\section{Conclusions}

In Greece, no specific legislation has been founded concerning patients suffering from MS and their families, which makes it difficult for them to face their daily needs due to their disease. Patients and their family members must be provided with a secure job or an extra benefit, which would ensure that they could cover their day to day needs as well as their out-of-pocket medical expenses.

Most patients with MS leave their jobs because they become severely ill. This could have been avoided if they had the option of a part time job. Flexible working hours is not the only intervention, as there are other suggestions, well applied abroad; i) employers and employees should be informed of how the disease affects patients' ability in order to make them more sensible. ii) a specific rest area for them to relieve so that they can keep on working.

Furthermore, organized scientific groups should be working altogether in order to point out and resolve problems concerning patients with MS and their carers. These services must be provided free of charge by the National Health System or by the social security organization.

Concluding, in Greece, research concerning the financial and social cost of MS must be encouraged because this will help unveiling the economic burden to patients, as well as to their family members, which will lead in taking the right measures in order to support them.

\section{References}

[1] Meader R.: Does the history of MS go back as far as the 14th century? ActaNeurol Scan. 60, 189-192 (1979).

[2] Papadopoulou X.: Answers to common questions for MS. Communicate. 7, 3-6 (2008).

[3] Newman JP, Maccoon DG, Vaughn LJ, Sadeh N.: Validating a distinction between primary and secondary psychopathy with measures of Gray's BIS and BAS constructs.J Abnorm Psychol. 114(2), 319-23 (2005).

[4] Traka M, Kraki E, Kygitsidou E, Patsiou A, Costa B, Baloyannis S.I.:Dystonic phenomena in MS patients hospitalized during 1992 - 2002, in the $1^{\text {st }}$ Department of Neurology of Aristotelian University of Thessaloniki, Archives of Neurology and Psychiatry. Encephalos. 4(41), 1-4 (2004).
[5] Prineas J, Wright RG.: Macrophages, lymphocytes and plasma cells in the perivascular compartment in chronic multiple sclerosis. Lab Invest. 38, 409-421 (1978)

[6] Koutsouraki E.: Living with MS. Impact on the family. Communicate. 8, 6-8 (2008).

[7] Zervas K.: The phenomenology of Chronic illness: The study of MS. Graduate Thesis Submitted for the degree of Msc in Health Care Management. Hellenic Open University. (2003).

[8] MULTIPLE SCLEROSIS INTERNATIONAL FEDERATION (MSIF). Disease courses in MS, MS in focus. 14, 4-14 (2009).

[9] DrTermou A.: Recent opinions and responses to gynecologic and obstetrics problems of demyelinating disease. Communicate. 10, 4-7 (2009).

[10] Koutsis G, Panas M.: Recent findings in the genetics of Multiple Sclerosis. Archives of Hellenic Medicine. 2, 135-150 (2008).

[11] Polikandrioti M, Kyritsi H.: Quality of life of patients with MS, Review. Nosileftiki. 45, 207-214 (2006).

[12] KurtzkeJF.: Epidemiology and etiology of Multiple Sclerosis. Phys Med RehabilClin N Am. 16, 327-349 (2005).

[13] Gourzoulidou EP.: Multiple Sclerosis in Western Greece Epidemiology of the disease and clinical study of the patients. Ph. D. Thesis. Faculty of Medicine. University Patras. 15-16(2008).

[14] Rabanis C.: MS: Social and Psychological aspects: Athens. Nissos Academic Publishing. 55 (2009).

[15] Papavasiliou A.: Early onset MS. Communicate. 8, 12-14 (2008)

[16] Henriksson F, Jonsson B.: The economic evaluation and consequences of multiple sclerosis. International MS Journal/MS Forum. 7(1), 9-17 (2008).

[17] KurtzkeJF.:Rating neurologic impairment in multiple sclerosis: an expanded disability status scale (EDSS). Neurology. 33(11), 1444-1452 (1983).

[18] KurtzkeJF.:A new scale for evaluating disability in multiple sclerosis. Neurology. 5, 580-583 (1995)

[19] Henriksson F, Fredrikson S, Masterman T, Jonsson B.: Costs quality of life and disease severity in multiple sclerosis: a cross sectional study in Sweden. Eur Neurol. 8, 27-35 (2001).

[20] Kobelt G, Berg J, Lindgren P, Fredrikson S, Jonsson B.: Costs and quality of life of patients with multiple sclerosis in Europe. $J$ NeurolNeurosurg Psychiatry.77, 918-926 (2006).

[21] Kobelt G, Lindgren P, Parkin D, Francis D, Johnson M, Bates D, Jonsson B.: Costs and Quality of life in multiple sclerosis: A Cross - Sectional Observational Study in the UK (This report is part of an observational study in three countries). Stockholm School of Economics Working Paper Series in Economics and Finance.398-399 (2000).

[22] Kobelt G, Lindgren P, Smala A, Jonsson B, THE GERMAN COST of MS STUDY GROUP.: Costs and Quality of life in multiple sclerosis: A Cross - Sectional Observational Study in the Germany (This report is part of an observational study in three countries). Stockholm School of Economics. Working Paper Series in Economics and Finance.399 (2000).

[23] Ceri JP, Humphreys I.: Assessing cost-effectivess in the management of multiple sclerosis.ClinicoEconomics and Outcomes research. 1, 61-78 (2009).

[24] Casado V, Martinez YS, Martinez YA, Carmona V, Alonso L, Romero L, Moral E, Gubieras L, Arbizu T.: Direct and indirect costs of Multiple Sclerosis in BaixLiobregat (Catalonia, Spain), according to disability. BMC Health Service Research. 6, 143 (2006).

[25] Kobelt G, Berg J, Lindgren P, Decoo D, Guillaume D, Neymark N, et al.: Costs and quality of life for patients with multiple sclerosis in Belgium.Eur J Health Econ.7, 24-33 (2006).

[26] Kobelt G, Berg J, Lindgren P, Elias WG, Flackenecker P, Friedel $\mathrm{M}$, et al.: Costs and quality of life for patients with multiple sclerosis in Germany. Eur J Health Econ. 7, 34-44 (2006).

[27] Trisolini M, Honeycutt A, Wiener J, Lesesne S.:Global economic impact of Multiple Sclerosis. MSIF. London. United Kingdom. 2268 (2010).

[28] Orologas A, Thomaidis G, Baloyianni E, Kalpatsanidis A, Daglis I, Tsantaki E.:The economic and social impacts of MS in GreecePilot study, $24^{\text {th }}$ annual congress of the Hellenic Neurological Society. Kos. 20th -23rd May (2010).

[29] KurtzkeJF.:Georgaphic distribution of multiple sclerosis: an update with reference to Europe and the Mediterranean region. ActaNeurol Scand. 62, 65-80 (1980). 
[30] Vickrey BG, Hays RD, Harooni R, Meyers LW.: A health related quality of life measure for multiple sclerosis. Qual Life Res. 4(3), 187-206 (1985).

[31] Hobart J, Lamping D, FitzpatrickR, RiaziA, ThompsonA.: The Multiple Sclerosis Impact Scale (MSIS-29). A new patient - based outcome measure. Brain. 124, 962-973 (2001).
[32] Andlin-Sobocki P, Jonsson B, Wittchen HU, Olesen J.:Costs of Disorders of the Brain in Europe. European Journal of Neurology, 12(1), 63-67 (2005).

[33] KapinaB.: The working ability of patients suffering from MS: Correlation of clinical, psychological and neuroradiological parameters. Ph. D. Thesis. Faculty of Medicine. Aristotle University of Thessaloniki. 102-116 (2009). 